Historic, archived document

Do not assume content reflects current scientific knowledge, policies, or practices. 

United States Department of Agriculture

Forest Service

Intermountain

Research Station

Research Paper

INT-379

Soluble Sugar

Concentrations in

Needles and Bark

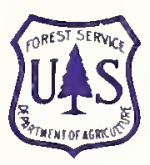

of Western White

Pine in Response

to Season and

Blister Rust

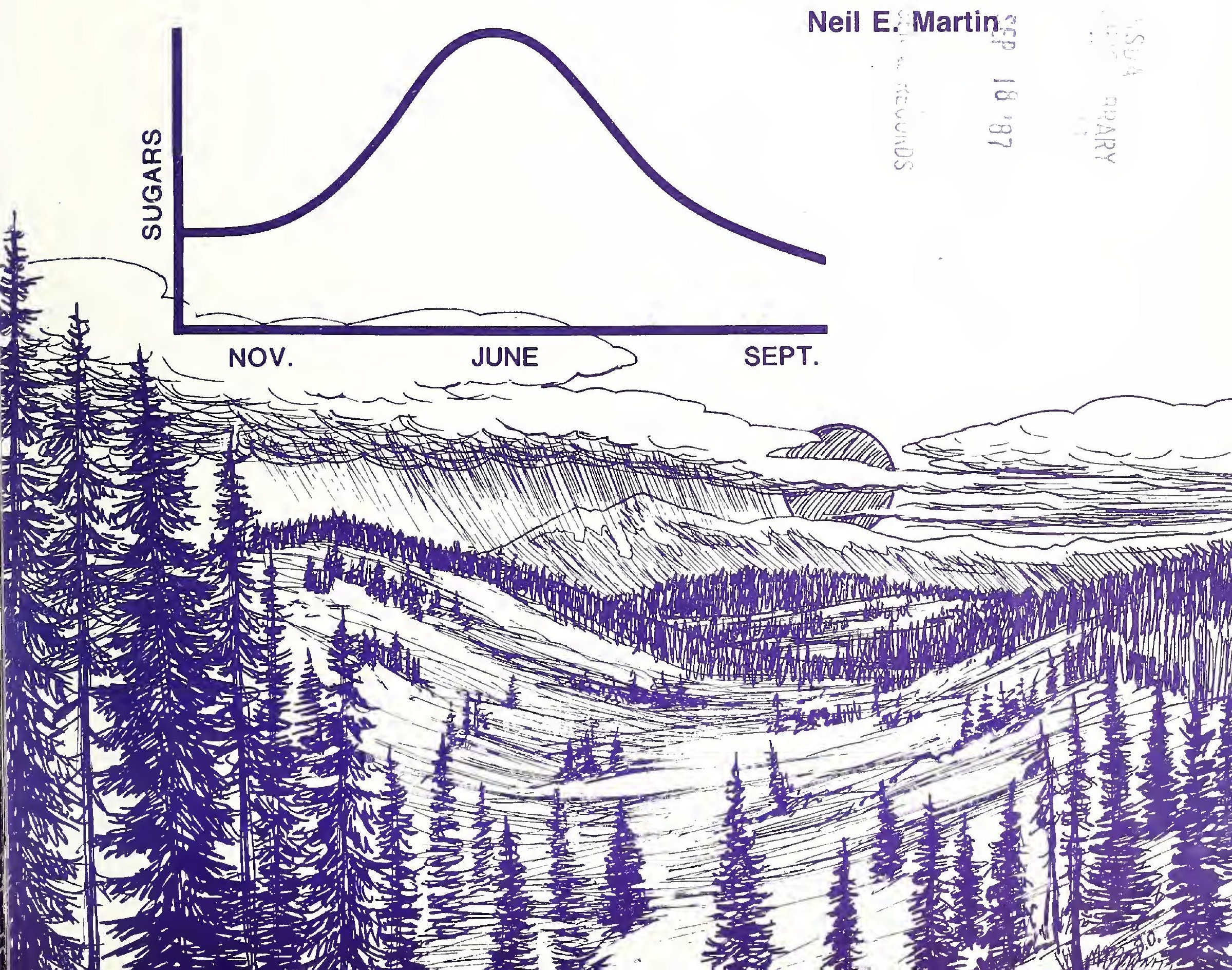




\section{THE AUTHOR}

NEIL E. MARTIN is a research plant pathologist at the Intermountain Research Station's Forestry Sciences Laboratory in Moscow, ID. He has researched the physiology of blister rust, damage due to dwarf mistletoe in various habitats, and the biology of root-rot-causing fungi on western conifers. Current research emphasizes ecology, pathogenicity, and fruiting of Armillaria species.

\section{RESEARCH SUMMARY}

Amounts of soluble sugars in certain tissues of 12- to 16-year-old western white pine (Pinus monticola Dougl.) trees, each with a blister rust canker girdling about 50 percent of the bole circumference, were compared with rust-free trees. Fructose, glucose, sucrose, raffinose, and stachyose extracted from needles and healthy and diseased bark were identified with thin-layer chromatography and quantified with a densitometer. The host's seasonal growth cycle induced changes in sugar concentrations in current, 1-, and 2-year needles, but the bole cankers did not. Amounts of bark sugars characterized the activities of the rust fungus (Cronartium ribicola J.C. Fisch.) as well as the fall, winter, and summer seasons. The amounts of sugars in the bark decreased toward the cankers' centers except for raffinose and stachyose. The greatest differences in amounts of sugars in rusted and nonrusted bark tissues were found in February. 


\title{
Soluble Sugar Concentrations in Needles and Bark of Western White Pine in Response to Season and Blister Rust
}

\author{
Neil E. Martin
}

\section{INTRODUCTION}

Qualitative and quantitative changes in soluble carbohydrates within conifer tissues occur throughout the year (Kozlowski and Keller 1966; Little 1970; Parker 1959; Zimmerman 1974). These changes are especially evident as responses to seasonal use and synthesis. Usually, monosaccharides and disaccharides predominate in needles and bark during the spring. As the flush of growth ceases and the newly expanded organs gain in net photosynthates, simple sugars are converted into oligosaccharides, illustrated in increases in raffinose and stachyose. Oligosaccharides characterize dormant conifer tissues. They do not remain indefinitely as storage molecules but are metabolized when ambient temperatures induce rapid growth the following spring.

Pathogens influence the metabolism of their host's tissues. This phenomenon has been studied extensively in many annual plant-obligate pathogen interactions and is known to include changes in respiration rates, photosynthesis rates, and qualitative and quantitative changes in metabolite pools (Brown 1936; Durbin 1967; Goodman and others 1967; Martin 1972; Schoeneweiss 1975; Siddiqui and Manners 1971; Welch and Martin 1975). Conversely, the metabolic or nutritional status of the host is known to influence the performance of some of its pathogens (Grainger 1956; Huber and Watson 1974; Schoeneweiss 1975). Changes in host physiology, such as those accompanying maturation or induced by climatic stimuli, may favor disease development (Allen 1966; Horsfall and Dimond 1957). In addition, the physiology of specific morphogenesis in the host appears necessary for, or is at least coincidental with, fungus morphogenesis. Chilling for 90 days at $2{ }^{\circ} \mathrm{C}$ satisfies the dormancy requirements and induces bud elongation in the white pine host; however, aecia production of Cronartium ribicola J.C. Fisch. commences only after, but not during, host dormancy (Wicker and Harvey 1969).

Because the soluble carbohydrate content of host conifers in the temperate zone reflects seasonal host physiology and because these sugars are also used by the obligatory blister rust fungus, it seemed that soluble sugar levels would be a sensitive measure of host and parasite demands. The objective of this research was to measure the effects of C. ribicola J.C. Fisch. and of seasons on the amounts of certain soluble sugars in the needles and in the bark of Pinus monticola Dougl.

\section{MATERIALS AND METHODS}

We selected 40 trees in a second-growth stand of 14- to 16-year-old western white pine growing on western white pine site 90 in an Abies grandis/Pachistima myrsinites habitat type (Daubenmire and Daubenmire 1968). This stand is $72 \mathrm{~km}$ east of Moscow, ID, in the Badger Meadows area of the East Fork of Potlatch Creek. We selected 20 trees with rust-infected stems and 20 with uninfected stems for uniformity in growth, size, habitat, and competition. Each infected tree had a canker in the lower half of the main stem that girdled 30 to 50 percent of the stem circumference. To alleviate the effects of branch infections on needle analysis, all branch cankers were removed 2 months before the first sampling and whenever additional infections became visible thereafter.

Each season, two or four cankered and canker-free trees were harvested for bark and needle samples. Bark was sampled at four locations on the diseased trees (Welch and Martin 1974): (1) sporulating areas: areas of blister rust cankers where pycnia and aecia are currently produced, (2) yellow margins: yellow canker boundary, (3) proximal: green bark proximal to the cankers but at least $1 \mathrm{~cm}$ away from the yellow margin, and (4) distal: green bark distal to a canker (always in the next higher growth segment to that of the canker). Bark was also sampled at two comparable bole locations on healthy trees. Although four diseased trees were individually sampled for needles in the field, the pulverized and freeze-dried samples of two trees had to be pooled to provide approximately 1 gram of freeze-dried tissue for analysis.

Three age classes of needles were sampled at random within each tree. Current-year, 1-year-old, and 2-year-old needles were sampled randomly from throughout the live crowns without regard to location of the bole canker. Three-year-old needles became senescent in June and were not sampled.

All samples were collected, quick-frozen on dry ice, and taken the same day to the laboratory where they were processed. Soxhlet extraction of all samples, clarification, 
thin-layer chromatography (TLC) of all extracts, and densitometric quantification of isolated sugars followed the methods described by Martin and Welch (1975) and Welch and Martin (1972).

Data from the needles were analyzed as a balanced factorial design using standard biometric techniques. Bark sugar data required the following model for an unbalanced factorial analysis (Snedecor 1956):

$$
Y_{i j k}=\mu+C_{i}+S_{j}+C S_{i j}+T_{k}+\varepsilon_{i j k}
$$

where

$$
\begin{aligned}
Y_{i j k}= & \text { dependent variables } \\
\mu & =\text { mean } \\
C_{i}= & \text { grouping of disease class and of bark samples }\left(C_{1}\right. \\
& =\text { diseased versus nondiseased; } C_{2}=\text { bark } \\
& \text { samples, } 1 \text { to } 4 \text { locations }) \\
S_{j}= & \text { seasons } \\
C S_{i j}= & \text { interaction between seasons and disease and bark } \\
T_{k}= & \text { trees. }
\end{aligned}
$$

\section{RESULTS}

Sugar concentrations in needles of cankered and cankerfree trees were indicative of the influence of seasons and of physiologic age (table 1). With the exception of sucrose, sugar levels, when considered collectively for all needles, showed a response to season through highly significant differences $(p=0.05)$ in the season means. Sucrose showed no statistically significant differences and less than half the variation found in the other sugars. Amounts of sugars within the November, February, and September collections decreased in the order fructose $>$ glucose $>$ sucrose $>$ raffinose $>$ stachyose. However, in the June collections, amounts of fructose were found to be similar or

\begin{tabular}{|c|c|c|c|c|c|c|}
\hline \multirow{2}{*}{$\begin{array}{l}\text { Tree } \\
\text { status }\end{array}$} & \multirow{2}{*}{$\begin{array}{c}\text { Needle } \\
\text { age }\end{array}$} & \multicolumn{5}{|c|}{ Sugar (mg/g dry tissue) ${ }^{1}$} \\
\hline & & Fructose & Glucose & Sucrose & Raffinose & Stachyose \\
\hline \multicolumn{7}{|c|}{ November } \\
\hline \multirow{3}{*}{$\begin{array}{l}\text { Diseased } \\
\text { trees }\end{array}$} & Current & 17.4 & 16.2 & 11.6 & 7.0 & 0.0 \\
\hline & 1 year & 16.8 & 14.8 & 13.6 & 8.1 & 0.0 \\
\hline & 2 years & 16.8 & 14.5 & 11.7 & 7.1 & 0.0 \\
\hline \multirow{4}{*}{$\begin{array}{l}\text { Rust-free } \\
\text { trees }\end{array}$} & Current & 16.2 & 15.0 & 13.3 & 7.5 & 0.0 \\
\hline & 1 year & 15.3 & 14.4 & -13.2 & 7.5 & 0.0 \\
\hline & 2 years & 15.5 & 13.5 & 13.8 & 6.6 & 0.0 \\
\hline & \multicolumn{6}{|c|}{ February } \\
\hline \multirow{3}{*}{$\begin{array}{l}\text { Diseased } \\
\text { trees }\end{array}$} & Current & 13.4 & 11.7 & 12.5 & 11.3 & 3.2 \\
\hline & 1 year & 14.7 & 12.1 & 9.9 & 10.6 & 2.9 \\
\hline & 2 years & 16.0 & 14.5 & 9.5 & 9.9 & 3.0 \\
\hline \multirow{4}{*}{$\begin{array}{l}\text { Rust-free } \\
\text { trees }\end{array}$} & Current & 14.7 & 13.4 & 12.4 & 10.9 & 3.2 \\
\hline & 1 year & 16.0 & 13.9 & 8.8 & 9.8 & 2.7 \\
\hline & 2 years & 15.6 & 13.8 & 10.9 & 7.8 & 2.7 \\
\hline & & & June & & & \\
\hline \multirow{3}{*}{$\begin{array}{l}\text { Diseased } \\
\text { trees }\end{array}$} & Current & 12.2 & 13.0 & 11.0 & Trace $^{2}$ & 0.0 \\
\hline & 1 year & 10.6 & 11.9 & 12.1 & Trace & 0.0 \\
\hline & 2 years & 11.1 & 11.1 & 9.9 & Trace & 0.0 \\
\hline \multirow{4}{*}{$\begin{array}{l}\text { Rust-free } \\
\text { trees }\end{array}$} & Current & 13.4 & 13.2 & 8.2 & Trace & 0.0 \\
\hline & 1 year & 11.8 & 12.0 & 11.6 & Trace & 0.0 \\
\hline & 2 years & 10.2 & 10.3 & 13.3 & Trace & 0.0 \\
\hline & \multicolumn{6}{|c|}{ September } \\
\hline \multirow{3}{*}{$\begin{array}{l}\text { Diseased } \\
\text { trees }\end{array}$} & Current & 17.4 & 16.6 & 10.6 & 3.8 & 0.0 \\
\hline & 1 year & 17.8 & 16.5 & 10.1 & Trace & 0.0 \\
\hline & 2 years & 18.2 & 16.3 & 10.3 & Trace & 0.0 \\
\hline \multirow{3}{*}{$\begin{array}{l}\text { Rust-free } \\
\text { trees }\end{array}$} & Current & 16.9 & 18.1 & 10.3 & Trace & 0.0 \\
\hline & 1 year & 19.8 & 17.2 & 9.6 & Trace & 0.0 \\
\hline & 2 years & 19.5 & 17.0 & 10.9 & Trace. & 0.0 \\
\hline
\end{tabular}
slightly greater than those of glucose. The seasonal patterns of amounts of fructose, glucose, and sucrose in all age classes of needles were similar, with the greatest amounts available in the needles sampled in the periods of slow tree growth (fall and winter) and the least amounts at the end of the accelerated growth period (June).

Table 1-Average concentrations of sugars in needles of blister rust-diseased and rust-free western white pines at four times during a growing season

${ }^{1}$ Average of four trees, each tree quantified by eight replicate TLC analyses of each sample (Welch and Martin 1972).

2The minimum threshold for accurate measurement was found to be approximately $3 \mathrm{mg}$. 
The effect of physiologic age of needles is best illustrated by comparisons of the amounts of raffinose. All age classes had trace amounts (approximately $3 \mathrm{mg} / \mathrm{g}$ ) in June and September. However, as needles age they apparently lose the capacity for certain oligosaccharide storage as indicated by the amounts of raffinose in the current needles decreasing to lesser amounts in 1-year-old and 2-year-old needles. Stachyose, another oligosaccharide, was also detected only in the February collections in all needle-age classes $(3.0 \mathrm{mg} / \mathrm{g}$, range 2.7 to 3.2$)$, but the influence of needle age on amount of stachyose accumulated was not evident. Comparisons of blister-rust-diseased and diseasefree trees showed no differences in these sugars between seasons or classes of needles.

All distal bark sampled in February and June had sugar" amounts decreasing in the order sucrose $>$ fructose $>$ glucose $>$ raffinose $>$ stachyose (table 2). Only comparisons of glucose in the distal bark of rust-diseased and rust-free trees in the February $(11.7 \mathrm{mg} / \mathrm{g}$ vs. $14.1 \mathrm{mg} / \mathrm{g})$ and September (12.2 mg/g vs. $14.9 \mathrm{mg} / \mathrm{g}$ ) collections showed significant differences. Concentrations of sucrose, raffinose, and stachyose in bark showed the following seasonal changes: sucrose occurred in the largest amounts in June (19.9 $\mathrm{mg} / \mathrm{g}$ ), then amounts receded through September to the smallest amounts in November $(14.4 \mathrm{mg} / \mathrm{g})$, then in increasing amounts through February $(16.6 \mathrm{mg} / \mathrm{g})$ to June. Raffinose and stachyose concentrations in the distal samples of diseased and rust-free trees responded to seasons differently from sucrose. Their peak concentrations were in the November $(12.5 \mathrm{mg} / \mathrm{g}, 8.4 \mathrm{mg} / \mathrm{g})$ and February $(9.4 \mathrm{mg} / \mathrm{g}, 10.2 \mathrm{mg} / \mathrm{g}$ ) collections, and their lowest concentrations in the June $(3.5 \mathrm{mg} / \mathrm{g}, 0.0 \mathrm{mg} / \mathrm{g})$ and September $(4.6 \mathrm{mg} / \mathrm{g}, 0.0 \mathrm{mg} / \mathrm{g})$ collections.

Proximal bark also contained all sugars in the same relative amounts as were found in the distal bark. Proximal bark sampled from trees affected and unaffected by the rust had similar amounts of each sugar (table 2). Sucrose levels had a higher concentration for February (12.1 $\mathrm{mg} / \mathrm{g}$ ) and a lower range of concentrations in proximal bark in healthy than in rust-affected trees; the differences were significant $(p=0.05)$. Proximal bark from both kinds of trees repeated the seasonal effects found in

Tab1e 2-Concentrations of sugars in bark tissues of blister rust-diseased and rust-free western white pines at four times during a growing season

\begin{tabular}{|c|c|c|c|c|c|c|}
\hline \multirow{2}{*}{$\begin{array}{l}\text { Tree } \\
\text { status }\end{array}$} & \multirow{2}{*}{$\begin{array}{l}\text { Location of } \\
\text { bark sample } \\
\text { in relation } \\
\text { to canker' }\end{array}$} & \multicolumn{5}{|c|}{ Sugar (mg/g dry tissue) $)^{2}$} \\
\hline & & Fructose & Glucose & Sucrose & Raffinose & Stachyose \\
\hline \multicolumn{7}{|c|}{ November } \\
\hline $\begin{array}{l}\text { Diseased } \\
\text { trees }\end{array}$ & $\begin{array}{l}\text { Distal } \\
\text { Proximal } \\
\text { Yellow margin } \\
\text { Sporulating area }\end{array}$ & $\begin{array}{r}15.0 \\
11.0 \\
9.2 \\
10.2\end{array}$ & $\begin{array}{r}12.8 \\
7.9 \\
5.9 \\
11.8\end{array}$ & $\begin{array}{r}14.4 \\
11.7 \\
9.1 \\
14.0\end{array}$ & $\begin{array}{l}12.5 \\
10.8 \\
10.8 \\
10.6\end{array}$ & $\begin{array}{l}8.4 \\
7.7 \\
7.7 \\
8.8\end{array}$ \\
\hline $\begin{array}{l}\text { Rust-free } \\
\text { trees }\end{array}$ & $\begin{array}{l}\text { Distal }^{3} \\
\text { Proximal }^{3}\end{array}$ & - & - & - & - & - \\
\hline \multicolumn{7}{|c|}{ February } \\
\hline $\begin{array}{l}\text { Diseased } \\
\text { trees }\end{array}$ & $\begin{array}{l}\text { Distal } \\
\text { Proximal } \\
\text { Yellow margin } \\
\text { Sporulating area }\end{array}$ & $\begin{array}{r}14.0 \\
16.8 \\
14.4 \\
3.1\end{array}$ & $\begin{array}{r}11.7 \\
12.9 \\
12.7 \\
3.3\end{array}$ & $\begin{array}{r}16.6 \\
12.1 \\
12.1 \\
4.8\end{array}$ & $\begin{array}{l}9.4 \\
6.8 \\
8.2 \\
3.6\end{array}$ & $\begin{array}{r}10.2 \\
6.5 \\
6.0 \\
5.2\end{array}$ \\
\hline $\begin{array}{l}\text { Rust-free } \\
\text { trees }\end{array}$ & $\begin{array}{l}\text { Distal } \\
\text { Proximal }\end{array}$ & $\begin{array}{l}14.3 \\
16.6\end{array}$ & $\begin{array}{l}14.1 \\
11.4\end{array}$ & $\begin{array}{l}16.1 \\
16.9\end{array}$ & $\begin{array}{l}9.2 \\
9.8\end{array}$ & $\begin{array}{l}8.6 \\
8.7\end{array}$ \\
\hline \multicolumn{7}{|c|}{ June } \\
\hline $\begin{array}{l}\text { Diseased } \\
\text { trees }\end{array}$ & $\begin{array}{l}\text { Distal } \\
\text { Proximal } \\
\text { Yellow margin } \\
\text { Sporulating area }\end{array}$ & $\begin{array}{l}15.5 \\
14.6 \\
11.3 \\
10.3\end{array}$ & $\begin{array}{r}13.3 \\
12.7 \\
9.9 \\
9.7\end{array}$ & $\begin{array}{l}19.9 \\
18.9 \\
15.7 \\
16.8\end{array}$ & $\begin{array}{l}3.5 \\
2.9 \\
3.2 \\
3.1\end{array}$ & $\begin{array}{l}0.0 \\
0.0 \\
0.0 \\
0.0\end{array}$ \\
\hline $\begin{array}{l}\text { Rust-free } \\
\text { trees }\end{array}$ & $\begin{array}{l}\text { Distal } \\
\text { Proximal }\end{array}$ & $\begin{array}{l}16.9 \\
11.6\end{array}$ & $\begin{array}{l}14.3 \\
10.4\end{array}$ & $\begin{array}{l}18.0 \\
16.0\end{array}$ & $\begin{array}{l}3.4 \\
3.1\end{array}$ & $\begin{array}{l}0.0 \\
0.0\end{array}$ \\
\hline \multicolumn{7}{|c|}{ September } \\
\hline $\begin{array}{l}\text { Diseased } \\
\text { trees }\end{array}$ & $\begin{array}{l}\text { Distal } \\
\text { Proximal } \\
\text { Yellow margin } \\
\text { Sporulating area }\end{array}$ & $\begin{array}{l}15.7 \\
14.3 \\
15.4 \\
12.0\end{array}$ & $\begin{array}{l}12.2 \\
12.7 \\
14.1 \\
10.6\end{array}$ & $\begin{array}{l}15.5 \\
15.0 \\
13.5 \\
11.7\end{array}$ & $\begin{array}{l}4.6 \\
5.3 \\
5.2 \\
4.7\end{array}$ & $\begin{array}{r}0.0 \\
0.0 \\
41.9 \\
4.0\end{array}$ \\
\hline $\begin{array}{l}\text { Rust-free } \\
\text { trees }\end{array}$ & $\begin{array}{l}\text { Distal } \\
\text { Proximal }\end{array}$ & $\begin{array}{l}17.7 \\
16.6\end{array}$ & $\begin{array}{l}14.9 \\
13.6\end{array}$ & $\begin{array}{l}12.9 \\
13.8\end{array}$ & $\begin{array}{l}5.2 \\
4.0\end{array}$ & $\begin{array}{l}0.0 \\
0.0\end{array}$ \\
\hline
\end{tabular}

${ }^{1}$ Distal $=$ green bark in the next high growth segment to that of the blister rust canker; Proximal $=$ green bark $1 \mathrm{~cm}$ away from the canker's yellow margin; Yellow margin = yellow bark at the leading boundary of the blister rust canker; Sporulating area = areas within the blister rust canker where pycnia and aecia are produced.

${ }^{2}$ Each sample quantified by eight replicated TLC analyses (Welch and Martin 1972).

3These tissues were not available for analysis.

4 The minimum threshold for accurate measurement was found to be approximately $3 \mathrm{mg}$. 
distal barks. For example, no seasonal trends were noted in amounts of fructose and glucose. Again, sucrose peaked in the June collection of proximal bark of cankered trees $(18.9 \mathrm{mg} / \mathrm{g})$ and showed the least amount in November $(11.7 \mathrm{mg} / \mathrm{g})$. Raffinose and stachyose were at their greatest concentrations in November (10.8 $\mathrm{mg} / \mathrm{g}, 7.7 \mathrm{mg} / \mathrm{g})$ and February $(6.8 \mathrm{mg} / \mathrm{g}, 6.5 \mathrm{mg} / \mathrm{g})$, with lesser amounts in June $(2.9 \mathrm{mg} / \mathrm{g}, 0.0 \mathrm{mg} / \mathrm{g})$ and September $(4.0 \mathrm{mg} / \mathrm{g}, 0.0$ $\mathrm{mg} / \mathrm{g}$ ).

Yellow margin bark (the yellowed bark that identifies the advancing margin of the blister rust canker) had significantly less fructose, glucose, and sucrose than either distal or proximal bark locations, but had similar levels of raffinose and stachyose (table 2). Seasonally associated trends in amounts of all sugars were found although patterns among seasons differed (table 2). Fructose and glucose were seasonally cyclic with alternating highs and lows. For example, fructose concentrations were low in November $(9.2 \mathrm{mg} / \mathrm{g})$, high in February $(14.4 \mathrm{mg} / \mathrm{g})$, lower in June $(11.3 \mathrm{mg} / \mathrm{g})$, and higher in September $(15.4 \mathrm{mg} / \mathrm{g})$. Seasonal values of sucrose concentrations were greatest in June $(15.7 \mathrm{mg} / \mathrm{g})$ and smallest in November $(9.1 \mathrm{mg} / \mathrm{g})$. Raffinose and stachyose were found in characteristically greater amounts in November $(10.8 \mathrm{mg} / \mathrm{g} .7 .7 \mathrm{mg} / \mathrm{g})$ and February $(8.2 \mathrm{mg} / \mathrm{g}, 6.0 \mathrm{mg} / \mathrm{g})$ rather than in June (3.2 mg/g, $0.0 \mathrm{mg} / \mathrm{g}$ ) and September $(5.2 \mathrm{mg} / \mathrm{g}, 1.9 \mathrm{mg} / \mathrm{g})$. Contrary to the decreases shown by distal and proximal samples, raffinose and stachyose each showed a slight increase in September ( $5.2 \mathrm{mg} / \mathrm{g}, 1.9 \mathrm{mg} / \mathrm{g}$ ) from the June low $(3.2 \mathrm{mg} / \mathrm{g}, 0.0 \mathrm{mg} / \mathrm{g})$.

The areas of the blister rust canker in which sporulation of the rust fungus occurs generally had smaller concentrations of each sugar than did other bark locations, and had a seasonal pattern unlike that of other bark samples. Table 2 illustrates that fructose and glucose concentrations were relatively similar in November $(10.2,11.8)$, June $(10.3,9.7)$, and September $(12.0,10.6)$ collections and at least three times the amounts (3.1 to 3.3) found in the February collections. Sucrose levels were consistent with those found in the other areas, except that the February (4.8) rather than November (14.0) samples contained the least amount. Amounts of raffinose in the sporulating areas deviated from the patterns found in the yellow margin samples, but stachyose showed no deviation. Concentrations of raffinose were consistently high in the November samples (10.6) but were depressed to lows similar to those for stachyose in the February (3.6). June (3.1), and September (4.7) collections.

\section{DISCUSSION}

The four sampling periods-November of one year, and February, June, and September of the following yearwere chosen to show that an obligate organism, the rust, is at times physiologically out of phase with its perennial host, the pine. For example, in our part of the temperate zone, the Northern Rocky Mountains, western white pine becomes dormant between September and November and its growth has noticeably slowed or stopped. However, blister rust growth such as canker enlargement and yellowing of the bark continue at a rate responsive to bark temperatures. That is, the rate decreases as temperatures decline and increases as bark temperatures increase. As early as February, the 14-week to 16-week cold temperature requirements for resumption of growth after dormancy of western white pine have been fulfilled (Steinhoff and Hoff 1972). Ambient temperatures of -12 to $2{ }^{\circ} \mathrm{C}$ continue host dormancy, but cankers enlarge whenever insolation increases bark temperatures to a level suitable for the blister rust fungus to grow.

April and May sampling periods were avoided because both organisms are metabolically very active at that time as evidenced in rapid changes in morphology-for example, current-year needle expansion, rapid leader growth, rapid canker enlargement, profuse aeciospore liberation, and pycniosori activity. These evident and dramatic changes are probably accompanied by rapid turnover within metabolic reservoirs of soluble sugars. By June, except for some canker enlargement, these activities have subsided and a balanced but dynamic equilibrium in sugar metabolism is likely reached between host and parasite.

Western white pines retain three generations of needles during any year. Researchers have found quantitative differences in starch, sugars, and nitrogen compounds between each generation of needles (Kozlowski and Keller 1966). In the research reported here, sampling was timed to minimize differences in amounts of soluble sugars brought about by the demands of host growth as well as the impact of immature or senescent needles. For example, although current-year needles were sampled twice in the year in which they were formed (June and September), both sampling dates were after the needles were fully expanded and are no longer juvenile but are considered as physiologically mature as 2- and 3-year-old needles. Needles in their third growing season and sampled in February of the following year are of comparable physiological maturity because they have remained green and free of the evidence of senescence that will appear later in April and May. These needles were not sampled in June because the 3 -year-old needles, now in their fourth growing season, were yellow to brown, indicating a probable bias in the analysis due to senescence and death effects.

Sugar concentrations in all needle age classes responded to growth activities of the host. Concentrations of sugars were greater during dormancy than active growth. Fructose and glucose concentrations, because of their direct involvement in catabolic as well as anabolic metabolism, were found to coincide closely with the demands of tree growth. Raffinose and stachyose were noticeable only as storage molecules in that they were measurable in dormant periods and undetectable in periods of active growth. In contrast, sucrose, a highly translocatable molecule, was found in similar concentrations in all samples. This suggests that, through translocation, pools of sucrose can have high turnover rates but be maintained at similar levels and therefore appear to be insensitive to host physiological activities.

Amounts of sugars in needles of these western white pines with bole cankers do not characterize the cankered trees nor distinguish them from healthy trees. Intuitively, stem infections could jeopardize the health of foliage as evidenced in diseases of many cultivated annuals, a phenomenon upon which aerial surveys rely. However, 
such is not the case in the perennial hosts having a perennial infection disproportionately small when compared to the biomass of the host. But as the blister rust cankers approach complete girdling of the stems (80 to 100 percent of the circumference), death of the portions above the cankers is evident; needle colors change from green to yellow to reddish brown. Before their rapid decline, however, all needles are of normal color and apparently are capable of near normal metabolism as is indicated by sugar concentrations found comparable to those in needles of healthy trees.

The impact by blister rust to soluble sugar pools in pine bark was measurable in June (Welch and Martin 1975). However, there were no apparent differences between seasons in amounts of fructose, glucose, and sucrose in bark located distally from the cankers compared to similarly located bark of noncankered trees. Infection depressed the canker levels of fructose and glucose without significantly altering sucrose levels. Although some differences are not significant, the implications within the data are that infections have an area of influence extending a limited distance beyond canker margins but does not include the foliage. These findings help explain the absence of an impact by the rust upon host growth (Buchanan 1938) until girdling of the bole is complete. That this disease affects only locally the amounts of certain sugars in certain tissues is also evident in the raffinose and stachyose concentrations. The seasonal concentrations of these sugars were unaffected by the presence of blister rust in another location on the bole. Regardless of blister rust, bark, like needles, showed sugar concentrations were highest during host dormancy and lowest during rapid growth.

Sugar concentrations in proximally located bark exhibited the same trends for each sugar as those found in the distal bark samples. Samples of proximal bark had smaller amounts of fructose, glucose, and sucrose, but similar amounts of raffinose and stachyose to those found in distal bark. The distal and proximal bark, although separated physically, are physiologically similar in their storage capacities for sugars as is evidenced in the similarity of raffinose and stachyose concentrations. Because the rust fungus is making its initial invasion into these tissues (Ehrlich and Opie 1940), the implications are that the lesser amounts of fructose, glucose, and sucrose are due to the metabolic demands of the neighboring, greater concentration of the fungus in the yellow margin.

Bark tissues inhabited by the blister rust fungus- the yellow margin of the cankers and the sporulating areasexhibited the same trends in sugar concentrations that characterized the proximal bark locations. As the sample locations progressed toward the canker centers, amounts of soluble fructose and glucose were less. This may show that small pools of these sugars reflect diminished needs after sporulation or that glucose has been synthesized into chitin, the glucosamine constituent of the fungal cell wall, a compound known to be present in this rust (Martin 1967).

The notable contrast in the low February levels of fructose, glucose, and sucrose in sporulating areas when compared to relative levels of the same sugars in other bark tissues in February also indicates that metabolism on the part of the blister rust fungus is greater than that of the pine tissues. Apparently, soluble sugars are being assimilated into aeciospores, which are subsequently dispersed from April through early June. Synthesis of pycnial fluid, which contains a high proportion of sugar alcohols and fructose (Wicker and others 1976), and synthesis of sugar alcohols in rust invaded bark (Welch and Martin 1975) would also utilize fructose at a time when host reserves in raffinose and stachyose are not available for maintaining a constant reservoir. Deductively, February is a period of late dormancy in the host and early spore development in the fungus in which the metabolism of pathogen and host are not synchronized in their rates of use of common pools of metabolites. This period may be a point in the life cycle of the pathogen at which it could be vulnerable to chemical attack while the host remains insensitive. This would achieve target selectivity in chemical control and minimize ecological impacts (Sbragia 1975).

\section{REFERENCES}

Allen, P. J. 1966. The role of the host in the development of disease symptoms-a review. Phytopathology. 56(3): 255-260.

Brown, W. 1936. The physiology of host/parasite relations. Botanical Review. 2: 236-281.

Buchanan, T. S. 1938. Blister rust damage to merchantable western white pine. Journal of Forestry. 36: 321-328.

Daubenmire, R.; Daubenmire, J. B. 1968. Forest vegetation of eastern Washington and northern Idaho. Tech. Bull. 60. Pullman, WA: Washington State University, Washington Agricultural Experiment Station, College of Agriculture. 104 p.

Durbin, R. D. 1967. Obligate parasites: effect on the movement of solutes and water. In: Mirocha, C. J.; Uritani, I., eds. The dynamic role of molecular constituents in plant-parasite interaction. St. Paul, MN: American Phytopathological Society: 80-99.

Ehrlich, J.; Opie, R. L. 1940. Mycelial extent beyond blister rust cankers on Pinus monticola. Phytopathology. 30: $611-620$.

Goodman, R. N.; Kiraly, Z.; Zaitlin, M. Vascular transport. 1967. In: The biochemistry and physiology of infectious plant disease. Princeton, NJ: D. Van Nostrand Co.: 281-307.

Grainger, J. 1956. Host nutrition and attack by fungal parasites. Phytopathology. 46: 445-456.

Horsfall, J. G.; Dimond, A. E. 1957. Interactions of tissue sugar, growth substances, and disease susceptiblity. Z. Pflanzenkr. Pflanzenpathol. Pflanzenschutz. 64: 415-421.

Huber, D. M.; Watson, R. D. 1974. Nitrogen form and plant disease. Annual Review of Phytopathology. 12: 139-165.

Kozlowski, T. T.; Keller, T. 1966. Food relations of woody plants. Botanical Review. 32: 293-382.

Little, C. H. A. 1970. Seasonal changes in carbohydrate and moisture content in needles of balsam fir (Abies balsamea). Canadian Journal of Botany. 48(1): 2021-2028.

Martin, N. E. 1967. Histochemical analysis of the blister rust fungus, Cronartium ribicola. Phytopathology. 57: 820-821. Abstract. 
Martin, N. E. 1972. Influence of blister rust on inorganic solute concentrations in western white pine. Phytopathology. 62(2): 226-229.

Martin, N. E.; Welch, B. J. 1975. Single dimension, multiple development thin-layer chromatography of sugars for densitometric quantification. Res. Note INT-192. Ogden, UT: U.S. Department of Agriculture, Forest Service, Intermountain Forest and Range Experiment Station. $7 \mathrm{p}$.

Parker, J. 1959. Seasonal changes in white pine leaves: a comparison of cold resistance and free-sugar fluctuations. Botanical Gazette. 121: 46-50.

Sbragia, R. J. 1975. Chemical control of plant diseases: an exciting future. Annual Review of Phytopathology. 13: 257-269.

Schoeneweiss, D. F. 1975. Predisposition, stress, and plant disease. Annual Review of Phytopathology. 133: 193-211.

Siddiqui, M. Q.; Manners, J. G. 1971. Some effects of general yellow rust (Puccinia striiformis) infection on 14-carbon assimilation, translocation, and growth in a spring wheat. Journal of Experimental Botany. 22(73): 792-799.

Snedecor, G. W. 1956. Statistical methods. Ames, IA: Iowa State University Press. 534 p.
Steinhoff, R. J.; Hoff, R. J. 1972. Chilling requirements for breaking dormancy of western white pine seedlings. Res. Note INT-153. Ogden, UT: U.S. Department of Agriculture, Forest Service, Intermountain Forest and Range Experiment Station. 6 p.

Welch, B. L.; Martin, N. E. 1972. Quantitative analysis of sugars by densitometric inspection of thin-layer chromatograms: analysis of method. Journal of Chromatography. 72: 395-364.

Welch, B. L.; Martin, N. E. 1974. Evidence of pectinase activity between Cronartium ribicola and Pinus monticola. Phytopathology. 64: 1287-1289.

Welch, B. L.; Martin, N. E. 1975. Effects of Cronartium ribicola on soluble sugars in Pinus monticola bark. Phytopathology. 65: 1025-1026.

Wicker, E. F.; Harvey, A. E. 1969. Dormancy and aecia production by Cronartium ribicola. Phytopathology. 59: 1057. Abstract.

Wicker, E. F.; Mosher, D. P.; Wells, J. M. 1976. Organic constituents of Cronartium ribicola pycnial fluid. Phytopathologische Zeitschrift. 87: 97-106.

Zimmerman, M. H. 1974. Storage, mobilization, and circulation of assimilates. In: Zimmerman, M. H.; Brown, C. L., eds. Trees: structure and function. New York: Springer-Verlag: 307-324.

Martin, Neil E. 1987. Soluble sugar concentrations in needles and bark of western white pine in response to season and blister rust. Res. Pap. INT-379. Ogden, UT: U.S. Department of Agriculture, Forest Service; Intermountain Research Station. $6 \mathrm{p.}$

Amounts of soluble sugars in certain tissues of 12- to 16-year-old western white pine (Pinus monticola) trees with blister rust cankers were compared with rust-free trees. The host's seasonal growth cycle induced changes in sugar concentrations in current, 1-, and 2-year needles, but the bole cankers did not. Amounts of bark sugars characterized the activities of the rust fungus (Cronartium ribicola) as well as the fall, winter, and summer seasons. The greatest differences in amounts of sugars in rusted and nonrusted bark tissues were found in February.

KEYWORDS: host-parasite physiology, Cronartium ribicola, Pinus monticola, soluble carbohydrates, disease influences, host responses, forest tree pathology

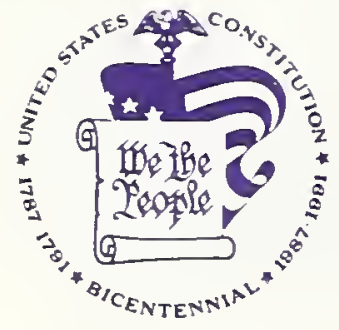

USDA policy prohibits discrimination because of race, color, national origin, sex, age, religion, or handicapping condition. Any person who believes he or she has been discriminated against in any USDA-related activity should immediately contact the Secretary of Agriculture, Washington, DC 20250. 